\title{
Comparison of the Effectiveness of the Chemosurgery and Cryosurgery for the Treatment of Patients with Condyloma Acuminatum
}

\author{
Prasetyadi Mawardi, Bobby Febrianto, Danu Yuliarto \\ Department of Dermatology and Venereology, Faculty of Medicine, Universitas Sebelas Maret/ \\ Dr. Moewardi General Hospital, Surakarta, Indonesia
}

\section{ABSTRACT}

Background: Condyloma acuminatum (CA) is one of the most common sexually transmitted infections. Several therapeutic modalities that can be used are chemosurgery with trichloroacetic acid and cryosurgery with liquid nitrogen. Recurrence in CA often occurs, so selecting the right therapeutic modality and eliminating the lesion also prevents recurrence. This study aimed to compare the effectiveness of chemosurgery and cryosurgery therapy in patients with CA who are treated at Dr. Moewardi Hospital Surakarta.

Subjects and Method: A retrospective crosssectional study was conducted at the Dermatology and Venereology Polyclinic, Dr. Moewardi Hospital, Surakarta, from January 1, 2018, to December 31, 2020. The study subjects were 78 patients diagnosed with CA based on ICD-10 criteria, while chemosurgery and cryosurgery procedures were based on ICD-9. The dependent variable was healing time in weeks. The independent variables were chemosurgery and cryosurgery therapy. The data came from the patient's medical record. Data were analyzed using an independent t-test.

Results: Based on univariate analysis, most patients were male $(67.9 \%)$, and the age group was 20-29 years $(51.28 \%)$. Most of the CA pa- tients work as private employees (46.15\%). The most sexual orientation was heterosexual (53.8\%), the most common site of lesions was genital (47.4\%), and 52.6\% were co-infected with HIV. Most CA patients received chemosurgery (70.5\%). Bivariate analysis showed that chemosurgery therapy provided faster clinical improvement $(\mathrm{Mean}=23.34 ; \mathrm{SD}=26.45)$ than cryosurgery therapy (Mean $=28.69 ; \mathrm{SD}=19.84)$, and the difference was statistically significant $(\mathrm{p}=0.037)$.

Conclusion: Treatment of CA using chemosurgery provides clinical improvement faster than cryosurgery, so that faster treatment time can reduce treatment costs and improve the patient's quality of life.

Keywords: chemosurgery, cryosurgery, HPV, condyloma acuminatum

\section{Correspondence:}

Prasetyadi Mawardi. Department of Dermatology and Venereology, Faculty of Medicine of Universitas Sebelas Maret/ Dr. Moewardi Hospital, Surakarta, Central Java, Indonesia. Email: prasetyadimawardi@gmail.com/ prasetyadi_m@staff.uns.ac.id. Mobile: +6281229750211.

Cite this as:

Mawardi P, Febrianto B, Yuliarto D (2021). Differences in the Effectiveness of Chemosurgery and Cryosurgery in Condyloma Acuminatum. Indones $\mathrm{J}$ Med. 06(03): 291-297. https://doi.org/10.26911/theijmed.2021.06.03.06.

cc) (i) (2) Indonesian Journal of Medicine is licensed under a Creative Commons

Attribution-Non Commercial-Share Alike 4.o International License.

\section{BACKGROUND}

Condyloma acuminatum (CA) is one of the most common sexually transmitted infections caused by the Human Papilloma Virus (HPV), especially HPV types 6 and 11
(Erickson et al., 2013). The incidence of CA worldwide is estimated at $160-289$ cases per 100,000 population annually (Patel et al., 2013), while the prevalence in Sanglah Hospital Bali in 2015-2017 was 5.48\% (Pus- 
pawati et al., 2018). At Dr. Moewardi Hospital, Surakarta, CA, was ranked first in the visits of sexually transmitted infections polyclinic patients (Mawardi et al., 2019).

Vela et al. (2018) stated that the management of CA generally aims to eliminate the lesions and prevent recurrence with minimal side effects. Sharma et al. (2017) reported a comparison of the effectiveness of cryosurgery as monotherapy and combination therapy using $25 \%$ podophyllin solution in CA patients, where the monotherapy group with cryosurgery provided a higher cure rate and lower recurrence rate than the combination therapy group. Fathi and Tsoukas (2014) research stated that using $80-90 \%$ trichloroacetic acid as monotherapy provides a cure rate of $70-80 \%$ with a recurrence rate of $36 \%$. Based on this description, we aimed to conduct this study to compare the effectiveness of chemosurgery and cryosurgery therapy so that it can be used as one of the considerations in choosing an effective, inexpensive, and easy-to-use $\mathrm{AC}$ therapy modality.

\section{SUBJECTS AND METHOD}

\section{Study Design}

A retrospective cross-sectional study was conducted at the Dermatology and Venereology Polyclinic, Dr. Moewardi Hospital, Surakarta, Central Java, Indonesia, from January 1, 2018, to December 31, 2020.

\section{Population and Sample}

The subjects of this study were 78 patients diagnosed with CA. They were treated and recorded in the medical records of the Dermatology and Venereology Polyclinic of Dr. Moewardi Hospital Surakarta based on the ICD-10 code. At the same time, the therapeutic measures were chemosurgery and cryosurgery based on the ICD-9 code.

\section{Study Variables}

The dependent variable was the duration of the patient receiving therapy until they were declared cured. The independent variables were chemosurgery or cryosurgery.

\section{Operational Definition of Variable}

Chemosurgery is a treatment procedure using chemical liquids that are destructive and applied topically.

Cryosurgery is a procedure to destroy abnormal tissue with very cold liquid nitrogen.

The duration of therapy is that the patient receives therapy once a week, starting from the first time treatment until it was declared cured.

\section{Study Instruments}

Our chemosurgery procedure used 80\% trichloroacetic acid solution, then applied two times using a cotton swab to the lesion area until the frosting appeared. The cryosurgery procedure uses liquid nitrogen using cryogen (Cry-ACß; Brymill Cryogenic Systems, Basingstoke, UKO) with an open spray technique. All KA patients received two freeze-thaw cycles for each lesion using a $\mathrm{C}$ nozzle (0.06 $\mathrm{mm}$ ) for the lesion freezing procedure. Spraying was carried out continously with a limit of $1 \mathrm{~mm}$ from the edge of the lesion until frosting appeared, where the distance between the nozzle and the surface of the lesion was 0.5$1 \mathrm{~cm}$.

\section{Data analysis}

The sample of research characteristics in the form of categorical data is presented in frequency and percentage. In contrast, the numerical data variables are presented in the form of mean, standard deviation, minimum, and maximum. The duration of therapy was the mean and standard deviation of the patient's week from the start of therapy until he was declared cured. The $\mathrm{t}$-test was used to compare the mean and standard deviation of the duration of 
Mawardi et al./ Chemosurgery and Cryosurgery in Condyloma Acuminata

therapy using chemosurgery and cryo-surgery, where the results were declared significant if the $\mathrm{p}$-value was $<0.050$.

\section{Research Ethics}

This research has received ethical approval from the Health Research Ethics Committee of Dr. Moewardi Hospital/ Sebelas Maret University Medical Faculty, Sura- karta, Central Java, Indonesia (440/I/HREC/ 2021).

\section{RESULTS}

\section{A. Sample Characteristics}

The sample characteristics in Table 1 showed the average age of the research subjects was 30.94 years $(\mathrm{SD}=10.96)$.

Table 1. Sample Characteristics (Continuous Data)

\begin{tabular}{lcccc}
\hline \multicolumn{1}{c}{ Variables } & Mean & SD & Min. & Max. \\
\hline Age (years) & 30.94 & 10.96 & 16.00 & 70.00 \\
Duration of chemosurgery therapy (weeks) & 23.34 & 26.45 & 8.00 & 84.00 \\
Duration of cryosurgery therapy (weeks) & 28.69 & 19.84 & 4.00 & 144.00 \\
\hline
\end{tabular}

Table 2. Sample Characteristics (Categorical Data)

\begin{tabular}{llcc}
\hline \multicolumn{1}{c}{ Characteristics } & \multicolumn{1}{c}{ Categories } & n & \% \\
\hline \multirow{2}{*}{ Gender } & Male & 53 & 67.9 \\
& Female & 25 & 32.1 \\
& 15-19 years & 4 & 5.13 \\
20-24 years & 20 & 25.64 \\
Age & 25-29 years & 20 & 25.64 \\
& 30-34 years & 12 & 15.38 \\
& 35-39 years & 10 & 12.82 \\
& 40-44 years & 3 & 3.85 \\
& 45-49 years & 3 & 3.85 \\
5O-54 years & 2 & 2.56 \\
Occupation & 35 years & 4 & 5.13 \\
& Student & 4 & 5.13 \\
& Univ student & 10 & 12.82 \\
& Housewife & 8 & 10.26 \\
Lesion location & Private worker & 36 & 46.15 \\
& Entrepreneur & 16 & 20.52 \\
Sexual orientation & Teacher & 2 & 2.56 \\
HIV infection & Civil servant & 2 & 2.56 \\
\multirow{5}{*}{ Therapy modalities } & Anorectal & 30 & 38.5 \\
& Genital & 37 & 47.4 \\
& Anorectal and Genital & 11 & 14.1 \\
& Heterosexual & 42 & 53.8 \\
& Homosexual & 24 & 30.8 \\
& Bisexual & 12 & 15.4 \\
& HIV (-) & 37 & 47.4 \\
& HIV (+) & 41 & 52.6 \\
& Chemosurgery & 55 & 70.5 \\
& Cryosurgery & 23 & 29.5 \\
\hline
\end{tabular}

Table 2 showed a total of 78 research subjects consisting of 53 men (67.9\%) and 25 women $(32.1 \%)$. The most age group of CA patients was 20-29 years (51.28\%), and most of them work as private employees as many as 36 people (46.15\%). The sexual orientation of most research subjects was heterosexual, amounting to 42 people (53.8\%). CA patients with HIV infection were 41 patients $(52.6 \%)$, while 37 patients 
(47.4\%) were without HIV infection. The highest predilection for CA was in the genital area in 37 patients (47.4\%). CA patients received cryosurgery in 24 cases (30.38\%) and chemosurgery in 55 cases $(69.62 \%)$, where the mean duration of treatment for all AC patients using chemosurgery was $23.34(\mathrm{SD}=26.45)$ weeks and KA therapy using cryosurgery was $28.69(\mathrm{SD}=19.84)$ week (Table 1).

Table 3. Comparison of the effectiveness of chemosurgery and cryosurgery based on the duration of therapy in weeks

\begin{tabular}{lccccc}
\hline \multirow{2}{*}{ Variable } & \multicolumn{2}{c}{ Chemosurgery } & \multicolumn{2}{c}{ Cryosurgery } & \multirow{2}{*}{ p } \\
\cline { 2 - 5 } & Mean & SD & Mean & SD & \\
\hline Duration of therapy (weeks) & 23.34 & 26.45 & 28.69 & 19.84 & 0.037 \\
\hline
\end{tabular}

Table 3 showed that there are differences in the effectiveness of chemosurgery and cryosurgery therapy in patients with KA who are treated at RSUD Dr. Moewardi Surakarta. Chemosurgery therapy gave faster clinical improvement (Mean= 23.34; $\mathrm{SD}=26.45$ ) than cryosurgery therapy (Mean=28.69; $\mathrm{SD}=19.84)$, and the difference was statistically significant $(p=0.037)$.

\section{DISCUSSION}

Condyloma acuminatum (CA) is a sexually transmitted infection caused by HPV and is still common worldwide. The prevalence of CA in the United States was reported to be 10-20\% (Scheinfeld, 2006). CA patients at the Dermatology and Venereology Polyclinic, Dr. Moewardi Surakarta for the period January 2013 - December 2017 totalled 94 patients (Nareswari et al., 2020). The incidence of $\mathrm{KA}$ is higher in men than women, with a ratio of 1: 0.7 , while by age, it mainly occurs in the age group of 20-39 years (Fleischer et al., 2001).

The results of our study the number of patients with RA was 78 patients, where the prevalence of CA was more prevalent in men $(67.9 \%)$ than women $(32.1 \%)$. The age group with the most CA cases in this study was 20-29 years (51.28\%). Puspawati et al. (2018) stated that the prevalence of CA was more common in men because women were generally embarrassed to seek treatment related to genital complaints and diffe- rences in anatomical structures. The study also stated that the incidence of CA mainly occurred in the 16-26-year-old group due to productive age and being sexually active.

Several studies mentioned work history to be one of the triggering factors for train transmission. The results of our study showed that the incidence of CA mainly occurred in patients who worked as private employees (46.15\%). Similar to the research conducted by Nareswari et al. (2020), the incidence of trains in private workers (61.7\%) is because private employees have flexible working hours, sufficient income, and extensive social interaction.

This study showed that the location of CA lesions was often found in the genital area in 37 cases $(47.4 \%)$. Wiraguna et al. (2019) reported many CA lesions in the genital area in 26 cases (43.3\%). The use of condoms during sexual intercourse cannot completely prevent the transmission of the virus, so abstinence from sexual intercourse for a certain period (coital abstinence) is an effective prevention method. This is because HPV can still be secreted at the base of the penis and scrotum, thereby increasing the risk of CA (de Sausa and Duraes, 2012).

Transmission of CA is primarily due to sexual intercourse, especially in high-risk populations. Several studies also mentioned that deviant sexual orientation is one of the factors that trigger the increasing preva- 
lence of CA. de Peder et al. (2010) reported the highest incidence of $\mathrm{AC}$ in the heterosexual group of $36.7 \%$ with an OR value of 0.20 (95\% CI= 0.12-0.66), where our results also showed that the incidence of $\mathrm{AC}$ was increased in the heterosexual group (53.8\%). Liu et al. (2015) stated that many sexual partners, especially 4-7 people, both with people infected with HPV or not, can increase the risk of $\mathrm{CA}$ and cervical cancer.

Most cases of CA can be accompanied by co-occurrence with HIV infection. The results of our study showed that there were 41 patients with RA with HIV infection (52.6\%), while 37 patients with CA without HIV infection (47.4\%). Patients with HIV infection have decreased levels of Langerhans cells, CD4, macrophages, neutrophils, and natural killer (NK) cells (Levi et al., 2005). Changes in the local immune system and a decrease in the number of memory $\mathrm{T}$ cells in the circulation that function to fight HPV infection will facilitate the occurrence of KA in tissues (Chaturvedi et al., 2009).

The main goal of KA treatment is to remove lesions, not as a therapy for HPV infection, but some patients with lesions that have disappeared will have a negative HPV test result (Lacey et al., 2013). CA patients with low $\mathrm{CD} 4$ cell counts experienced clinical improvement after six treatment sessions using 90\% TCA solution (Loftabai et al., 2015). Research conducted by Uyar and Sacar (2014) reported that the 7-8 day interval of each cryosurgery session proved to be more effective for CA than the 14-21 day interval. The results of the t-test of this study showed that chemosurgery provided faster clinical improvement than cryosurgery based on the duration of therapy in weeks, and the results were statistically significant $(\mathrm{p}=0.037)$.

The use of topical therapy, including chemosurgery, is still the first line of treatment for $\mathrm{CA}$ and in multiple lesions. The
80-90\% trichloroacetate solution is also easy to obtain and use, especially in primary care facilities or tertiary hospitals. The cure rate for chemosurgery is higher (56-81\%) compared to cryosurgery (44$75 \%)$, while the recurrence rate is lower in chemosurgery (36\%) than cryosurgery (42\%) (Lacey et al., 2013). Scheinfeld (2006) stated that cryosurgery is more expensive and cannot be done for lesions that have shrunk, so topical therapy is needed for complete healing.

The advantage of this study is to compare the effectiveness of the two modalities of CA therapy in heterosexual, homosexual, and bisexual groups and their use in the genital, anorectal, or both areas. One of the limitations of this study is that it is a retrospective study, so we could not evaluate the recurrence rate of the two treatment modalities. We hope that further studies can be carried out to compare the effectiveness of the two therapies to prevent a recurrence.

\section{AUTHOR CONTRIBUTION}

Prasetyadi Mawardi did the study concept, examined vascular endothelial growth factor expression, and drafted the manuscript. Bobby Febrianto and Danu Yuliarto did the data collection and finding references.

\section{FUNDING AND SPONSORSHIP}

This study was self-funded.

\section{CONFLICT OF INTEREST}

There was no conflict of interest in this study.

\section{ACKNOWLEDGEMENT}

The authors conveyed acknowledgments to the director of the Dr. Moewardi Hospital for allowing this study to be carried out. Thank you to all the health personnel for helping in data collection. Thank you to all 
the patients who had been willing and cooperative to become the study subjects.

\section{REFERENCE}

Chaturvedi AK, Madeleine MM, Biggar RJ, Engels EA (2009). Risk of human papillomavirus-associated cancers among persons with AIDS. J Natl Cancer Inst. 101(16): 1120-30. https://doi.org/10.1093/jnci/djp205.

de Peder LD, da Silva CM, Madeira HS, Malizan JA, Nascimento BL, Horvath JD, et al. (2011). Predictors associated with and the prevalence of condylomata acuminata infection among people in Southern Brazil. Health Sci J. 11(1): 22-30. https://doi.org/10.21876/rcshci.v11i1.1021.

de Sousa JB, Duraes L (2012). Human papilloma virus and anal cancer. In: Malla N (editor). Human papillomavirus and related diseases-From bench to bedside-A clinical perspective. Kroasia: InTech.

Erickson B, Alvarez R, Huh W (2013). Human papilomavirus: what every provider should know. Am J Obstet Gynecol. 208: 169-75. https://doi.org/10.1016/j.ajog.2012.09.007.

Fathi R, Tsoukas MM (2014). Genital warts and other HPV infections: Established and novel therapies. Clin Dermatol. 32(2): 299-306. https://doi.org/10.1016/j.clindermatol.2013.08.014.

Fleischer AB, PArrish CA, Glenn R, Feldman SR (2001). Condylomata acuminata (genital warts): Patients demographics and treating physicians. Sex Transm Dis. 28(11): 643-7. https://doi.10.1097/00007435-200111000o0006.

Lacey CJN, Woodhall SC, Wikstrom A, Ross J (2013). 2012 European guideline for the management of anogenital warts. J Eur Acad Dermatol Venereol.
27: 263-70. https://doi.org/10.1111/j.1468-3083.2012.04493.x.

Levi G, Feldman J, Holman S, Salarieh A, Strickler HD, Alter S, Minkoff $\mathrm{H}$ (2005). Relationship between HIV viral load and Langerhans cellls of the cervical epithelium. J Obstet Gynaecol Res. 31(2): 178-84. https://doi.org/10.1111/j.1341-8076.2005.00267.x

Liu ZC, Liu WD, Liu YH, Ye XH, Chen SD (2015). Multiple sexual partners as a potential independent risk factor for cervical cancer: a meta-analysis of epidemiological studies. Asian Pac J Cancer Prev. 16(9): 3893-3900. https://doi.org/10.7314/APJCP.2015. 16.9.3893

Lotfabai P, Maleki F, Gholami A, Yazdanpanah MJ (2015). Liquid nitrogen cryotherapy versus $70 \%$ trichloroacetic acid in the treatment of anogenital warts: A randomized controlled trial. Iran J Dermatol. 18(4): 151-55. https://www.sid.ir/en/journal/ViewP aper.aspx?id $=546171$.

Mawardi P, Rosita F, Fitriani F, Dian EDN. Profil Infeksi Menular Seksual di RSUD Dr. Moewardi 2016-2018. Proceeding Book. 6th International Conference on Public Health 2019. Solo-Central Java, Indonesia.

Nareswari A, Mawardi P, Kusumawardani A, Ellistasari EY (2020). Gender differences in sociademographic characteristics and risk factors among condyloma acuminata patients in Dr. Moewardi General Hospital Surakarta. Jurnal Profesi Medika. 14(2): 205-9. http://dx.doi.org/10.33533/jpm.v14i2 .2169 .

Patel H, Wagner M, Singhal P, Kothari S (2013). Systematic review of the incidence and prevalence of genital warts. BMC Infectious Diseases. 13(1): 1-14. 
Mawardi et al./ Chemosurgery and Cryosurgery in Condyloma Acuminata

https://doi.org/10.1186/1471-233413-39.

Puspawati NMD, Sissy S, Gotama D (2018). A retrospective study of condyloma acuminata profile in outpatient clinic of dermato-venereology Sanglah General Hospital Denpasar, Bali-Indonesia period 2015-2017. Bali Dermatol Venereol J. 1: 1-3. 10.15562/bdv.v1i1.1.

Scheinfeld N (2006). Genital warts. Dermatol Online J. 12(3): 5. https://doi.org/10.5070/D37v57p744.

Sharma N, Sharma S, Singhal C (2017). A comparative study of liquid nitrogen cryotherapy as monotherapy versus in combination with podophyllin in the treatment of condyloma acuminata. $\mathrm{J}$ Clin Diagn Res. 11(3): 1-5. 10.7860/JCDR/2017/23797.9339.
Uyar B, Sacar H (2014). Comparison of cryotherapy session intervals in the treatment of external genital warts. Dermatologica Sinica. 32(3): 154-6. https://doi.org/10.1016/j.dsi.2013.10. 002.

Vela S, Videla S, Ornelas, A, Revollo B, Clotet B, Sirera G, et al. (2018). Effectiveness of physically ablative and pharmacological treatments for anal condyloma in HIV-infected men. PloS one. 13(8): 1-11. https://doi.org/10.1371/journal.pone.0199033

Wiraguna AAGP, Andriani PI, Adiguna MS (2019). Comparison of plasma zinc levels among HIV+ and HIV- subjects infected with condyloma acuminata. Asian Pac J Cancer Prev. 20(3): 94349. https://doi.org/10.31557/APJCP.2019.20.3.943. 